\title{
A dynamic causality analysis between gold price movements and stock market returns: Evidence from India
}

\author{
Anil Kumar Bhuyan 1,*, Ajit Kumar Dash ${ }^{2}$ \\ ${ }^{1}$ Research Scholar, ${ }^{2}$ Assistant Professor, School of Management, Birla Global University, Bhubaneswar, Odisha, India
}

*Corresponding Author:

Email: anil.bhuyan.ltd@gmail.com

\begin{abstract}
Indian economy is a developing economy and one of the largest gold importers globally. During the financial year 2016-17 India imported around 550 tonnes of the metal and during the financial year, it will jump to 846 tonnes (MMTC-PAMP). According to the Ministry of Commerce \& Industry (August 2017), the Imports during May 2017 which were valued at US \$ 35462.79 million (Rs 226849.74 crore) and gold showing the highest growth rate $(68.90 \%)$ growth in August 2017 over the corresponding month of last year. This paper empirical evidence on the relationship between the gold price and the NSE Nifty stock index in India by using monthly data from January 2001 to December 2017. The Augmented Dickey-Fuller unit root test, Granger Causality Test and Johansen's Co-integration test have been applied. Results of the Johansen's Co-integration indicate that there is long-run equilibrium relationship between gold price and stock returns. Further, the Granger causality test results indicate that there is no causal relation between gold and stock return and finally the impulse response functions show that the gold and the response of the stock return is positive at each time responsive period and it can be said that the response of both the variables has a smooth fluctuation in upcoming 10th period.
\end{abstract}

Keywords: Gold Prices, Stock Market Return, Nifty, Granger Causality Test and Johansen's Co-Integration Test. JEL Classification: C32, F13, F43, G12.

\section{Introduction}

Gold has its importance from the traditional days because of its importance as a valuable asset. It has been a symbol of status in the society and considered to be an investment by the people. According to the Gems and Jewellery Export Promotion Council (GJEPC) and (money control). By the end of the Dec 2017, Indian gold import will increase to 700 tonnes and earlier it was 500 tonnes in 2016-17. Today, India is the largest gold importer after Hong Kong and Switzerland. This indicates that the importance of gold is more than the traditional logics (i.e. a symbol of social status, conservative investment and valuable asset). The increasing demand of gold is not only due to the reasons of investment and uses only; rather there are some other reasons which influence the demand for gold in Indian domestic market. The investment behavior of Indian population is observed to be changing and the literature envisages that the demand for gold may be having a causal relationship with the other investment options and stock market behavior. The volatility of market panics the investors and makes the investment decisions difficult and risky. The investor might be choosing a traditional safe option for investment and gold can be a best option. So, deep uncertainty in stock market returns due to its volatility may have a causal relation for movement in gold price and which might be influencing the demand for gold. In this context, the present paper is an attempt to examine the causal relationship between gold price movement and stock market returns in the Indian context.

The present paper having five sections, where section-II provides a brief review of the literature regarding the relationship between the gold price and stock returns. Section-V describes the data and methodology of the research work. Section-IV provides the empirical analysis of the data and discussion of results while Section- $V$ concludes the research with some policy implication.

\section{Literature Review}

Literature relating to the gold price and stock indices

Investing in Gold has been considered as a reliable and "safe haven" investment for stock markets because it has a steady, stable value in the different market situation. In recent years, the global finance industries have witnessed a series of financial crises which have substantial negative impacts on stock market investment returns and suffered losses. For example, at the time of global financial crisis 2007-08, the majority sectors of the different stock exchanges around the world is falling down excepts the yellow metal (gold). At that time gold market gives a tremendous response and derives the investors attentions to add gold in their investment portfolios for investment purposes (Beckman et al., 2014).

Generally, the investors are always looking for the protection of their investment portfolios, and gold has acted as a reliable Asset for them because the gold price and the growth of the stock market move in opposite directions. Whereas both gold price and stock are often substitutes for each other. Generally, there a reverse relationship exists between the gold and stock prices because when the gold price goes down, the investors are diversified their investment from gold to stock market and vice versa. In this context, numerous studies were 
made for comparing and analyzing the returns of the Gold and the stocks and reported different results. For instance, Smith, (2001); Levin \& Wright, (2006); Mishra et al. (2010); Nguyen et al., (2012); Ray, (2013); Sreekanth \& Veni, (2014) observed that there is a significant correlation between gold prices and stock return. Whereas Toraman et al., (2011); Shahzadi \& Chohan, (2012); Baig et al., (2013) found a high negative correlation between gold prices and US stock return.

Mishra et al., (2010) examined the volatility of gold price and stock market in India by considering the domestic gold prices and stock market returns based on BSE 100 index during the period of 1991-2009 by applying the Granger Causality test in VAR framework and finds that the gold prices granger causes stock returns in India and vice versa. However, the study of the Shahzadi \& Chohan, (2010) and Baig et al, (2013) conduct study on impact of gold prices on stock exchange during the period of 2006-2010 by using Granger Causality Test in VAR framework to find the impact of gold prices on Karachi Stock Exchange and find out that there is a negative Correlation between the gold prices and Karachi stock exchange indices. Wang et.al., (2011) examined the oil price, gold price, exchange rates of the dollar vs various currency stock markets of Germany, Japan, Taiwan, China, and the USA and found that there Is a long-term stable relationship among these countries except the USA. Similarly, another studies of Bali \& Cinel, (2011) measures the effect of gold prices on the Istanbul Stock Exchange by using panel data analysis and conclude that gold prices do not have a direct effect on ISE 100 Index. Toraman et al,. (2011) proved that there is a high negative correlation between gold prices and US exchange rates.

Mulyadi \& Anwar, (2012) compared stocks and gold investments by using probit economic model during the period of 1997-2011 conclude that the gold investment was more advantageous than stock investment.

Bhunia and Das, (2012) conducted a study to examine the causal relation between gold prices and stock exchange returns were by applying the Granger Causality approach and find out that during and after financial crisis the movements of the gold price and stock price moves in a tandem, because Indians not only consider gold as a jewellery but also consider as a safe investment in gold bonds and equities. Moreover, Narang \& Singh, (2012) evidenced that there is no causality between the investment in gold price and the stock market in India.

Srinivasan \& Karthigai, (2014) conducted a study to investigate the causal relationship between gold price, stock price and exchange rate in India for the period from June 1990 to April 2014 by using ARDL approach and Granger causality test and find out that gold price and stock price tend to have long-run relationship with exchange rate in India and the study also indicates that there exists no causality from gold price to stock price or vice versa in the short run. Gayatri \& Dhanabhakyam, (2014) studied the relationship between the gold price and stock return during the period of 2003-2013 and found that gold price and stock return were changing significantly and there is a need to validate the relationship.

However, the recent study of the Srinivasan \& Prakasam, (2015) investigated the causal relationship between gold price, stock price and exchange rate by using the ARDL approach and Granger causality test in India and found that gold price and stock price tend to have long-run relationship with exchange rate in India but in short-run there is no casual relationship between gold price to stock price and vice versa. Chkili, (2016) examined the dynamic relationships between gold and stock markets in BRICS countries by using A-DCC model during the turbulent period of 2000-2014 and find out that there is a time-varying correlation between gold and stock markets and they also find out that during the crises period the correlation is low, and it is almost negative. Moreover, the study of the Naveed et al., (2016) examined the hedge and safe haven characteristics of gold and Islamic stocks for BRICS in episodes of financial downturns for the period of 1996 to 2014 by using Wavelet Coherency, Cointegration Model and proved that gold maintain its role as hedge for stock markets over short-run and in financial and economic crises periods and concludes that in Asian financial crises, gold proves as a strong safe haven for BRICS and Islamic index. Another study of Kumar, (2014) mentioned that gold-stock portfolio provides better diversification benefits than the stock portfolios.

From the above literature study, it is concluded that the domestic gold price does not contain any significant information to forecast stock prices in India. From the past literature it is cleared that weather there is a bidirectional or unidirectional relationship between gold and stocks or mixed response with respect to the relationship between gold and stocks returns under different time periods, and different geographical location as well as the different methodology applied by different author in their study. But, still the empirical results of the above research findings reflect that the issue lacks consensus and signifies the importance of additional evidence on this topic. Therefore, the present study will investigate is there any co-integration and causal relationship between gold return and NSE Nifty returns in Indian market.

\section{Objectives of the Study}

1. To compare the trend of the Gold returns and Nifty returns.

2. To investigate the cointegration and causal relationship between gold prices and NSE Nifty returns.

3. To determine the direction of the relationship between the gold prices and NSE Nifty returns. 


\section{Data and Research Methodology}

This section explains the data and methodology of the paper. It has been partitioned into two subsections. The first subsection gives the data and its sources, sample and period of the study. The next subsection relates to the methodology and procedures.

\section{Data and Data Sources}

The paper evaluates the long run as well as short-run (causal) relationship between gold prices and stock market returns in India. The study was conducted by using secondary monthly time series data covering a period of seventeen years from 2001 to 2017. The monthly data of gold price of Rupee value unit per troy ounce of gold and NSE CNX Nifty have been collected from the websites of World Gold Council and National Stock Exchange Database. The monthly price of gold data in ounce is converted into 10 grams by using Gold $10 \mathrm{gm}$ price $=($ ounce price $/ 28.35) * 10$ and further from the 10 grams price is converted to monthly gold return (GOLDRETURN). Similarly, the monthly closing price of the NSE Nifty is converted to Nifty returns (NIFTYRETURN) by using [(p1-p0)/p0].

\section{Materials and Method}

To analyze the cause and impact relationship between gold price and stock market return with reference to nifty both in long run as well as short run the Globally accepted econometric techniques like, ADF Unit Root Test, Granger Causality Test and Johansen's Co-integration test followed by Mishra et al. (2010); Bali \& Cinel (2011); Shahzadi \& Chohan (2010); Baig et al. (2013); Gayatri \& Dhanabhakyam (2014); Srinivasan \& Karthigai, (2014); srinivasan \& Prakasam, (2015); Naveed et al., (2016).

\section{Step -1 Testing Unit-Roots}

To check the stationarity/ unit root of the data series Augmented Dicky-Fuller test statistic is applied. This test is normally used to check the stationarity and trend stationarity of the time series data. The Augmented Dicky-Fuller statistic, used in the test, is a negative number. More negative is the stronger rejection of hypothesis. The Augmented

Dicky-Fuller statistic is measured by applying $\Delta \mathrm{Y}_{\mathrm{t}}=\alpha+\beta_{\mathrm{t}}+\gamma \mathrm{y}_{\mathrm{t}-1}+\delta_{1} \Delta \mathrm{Y}_{\mathrm{t}-1}+\cdots+\delta_{\mathrm{p}-1} \Delta \mathrm{Y}_{\mathrm{t}-\mathrm{p}+1}+$ $\varepsilon_{\mathrm{t}}$.

Where: $\alpha=$ constant, $\beta=$ coefficient on a time trend, $p$ $=$ the lag order of the autoregressive process

On the other hand, we have applied The PhillipsPerron Unit Root Tests. This test is different from the above ADF test because it mainly dealt with serial correlation and heteroskedasticity in the error terms. Generally, ADF tests use a parametric auto-regression to approximate the ARMA structure of the errors in the test of regression, where the PP tests ignore the serial correlation in the test regression. The test regression for the PP tests is-

$\Delta \mathrm{y}_{\mathrm{t}} \quad \beta^{\prime} \mathrm{Dt} \quad+\quad \pi \mathrm{y}_{\mathrm{t}-1}+\quad \varepsilon_{\mathrm{t}}$

(3)

Where $u_{t}$ is $I(0)$ and may be heteroskedastic. The PP tests correct for any serial correlation and heteroskedasticity in the errors $\varepsilon_{\mathrm{t}}$ of the test regression by directly modifying the test statistics $t_{\pi}=0$ and $T \hat{\pi}$.

\section{Step-2 Testing for Co-integration and Causation Testing for Co-integration Using Johansen's approach}

The Johansen Cointegration test is an econometric test of time series variable which predicts the long run or equilibrium economic relationship between two or more time-series variables based on the augmented DickeyFuller test and having unit roots. This approach mainly determines the number of co-integrated vectors for any given number of non-stationary variables of the same order. That means two or more random variables are said to be cointegrated if each of the series is themselves non - stationary. The Johansen Cointegration approach basically takes its starting point in the vector autoregression (VAR) of order $\mathrm{p}$ given by

$\mathbf{y}_{\mathrm{t}}=\boldsymbol{\mu}+\mathbf{A}_{1} \mathbf{y}_{\mathrm{t}-1}+\ldots \ldots+\mathbf{A} p \mathbf{y}_{\mathrm{t}}-\mathrm{p}+\boldsymbol{\varepsilon}_{\mathrm{t}}$ ............................................. (4) where, $\mathbf{y}_{\mathrm{t}}$ is a $\mathrm{nx} 1$ vector of variables that are integrated of order one - commonly denoted I (1) - and $\varepsilon_{t}$ is an nx 1 vector of innovations. This VAR can be re-written as $\Delta \mathrm{y}_{\mathrm{t}}=\mu+\prod_{\mathrm{t}-1}+\sum_{\mathrm{i}=1}^{\mathrm{p}-1} \Gamma_{\mathrm{i}} \Delta \mathrm{y}_{\mathrm{t}-1}+\varepsilon_{\mathrm{t}}$ Where $\Pi=\sum_{i=1}^{p-1} A_{i}-I$ and $\Gamma_{i}=-\sum_{j=i+1}^{p} A_{j}$

\section{Testing for causation using Granger Causality approach in VAR framework}

The Granger causality test is a statistical hypothesis which investigate whether one data series variable have sufficient enough to predict/forecasting another data series in a particular period.it has the ability to predict the future value of the time series by using historical data of another time series (Granger, 1969, 1988). The present study follows the Granger Causality approach in VAR framework. Suppose there are two variables $X$ and $Y$ then Granger causality analysis in the VAR framework will be based on the following equations.

$$
\begin{aligned}
& \Delta \mathrm{X}_{\mathrm{t}}=\alpha_{\mathrm{x}}+\sum_{\mathrm{i}=1}^{\mathrm{k}} \beta_{\mathrm{x}, \mathrm{i}} \Delta \mathrm{X}_{\mathrm{t}-\mathrm{i}}+\sum_{\mathrm{i}=1}^{\mathrm{k}} \gamma_{\mathrm{x}, \mathrm{i}} \Delta \mathrm{Y}_{\mathrm{t}-\mathrm{i}}+\varepsilon_{\mathrm{x}, \mathrm{t}} \\
& \text { …............................... (6) } \\
& \Delta \mathrm{Y}_{\mathrm{t}}=\alpha_{\mathrm{y}}+\sum_{\mathrm{i}=1}^{\mathrm{k}} \beta_{\mathrm{y}, \mathrm{i}} \Delta \mathrm{Y}_{\mathrm{t}-\mathrm{i}}+\sum_{\mathrm{i}=1}^{\mathrm{k}} \gamma_{\mathrm{y}, \mathrm{i}} \Delta \mathrm{X}_{\mathrm{t}-\mathrm{i}}+\varepsilon_{\mathrm{y}, \mathrm{t}}
\end{aligned}
$$

\section{Empirical Results Analysis and Discussion}

The whole analysis is based on both descriptive as well as empirical. The first part of this section provides the descriptive results of trend of gold and nifty returns in India during January 2001 to December 2017 and the second part of this section provides the empirical results. 
The empirical results are based on the methodology, discussed in the current section. The results have been provided in two parts: the first part gives the preliminary results of unit-root test and correlation and the second part focuses on the impact of Gold price on the Stock market returns by applying Johansen's Co-Integration test and Granger causality test approach in VAR framework.

\section{Trend of Gold Returns and Nifty Returns in India}

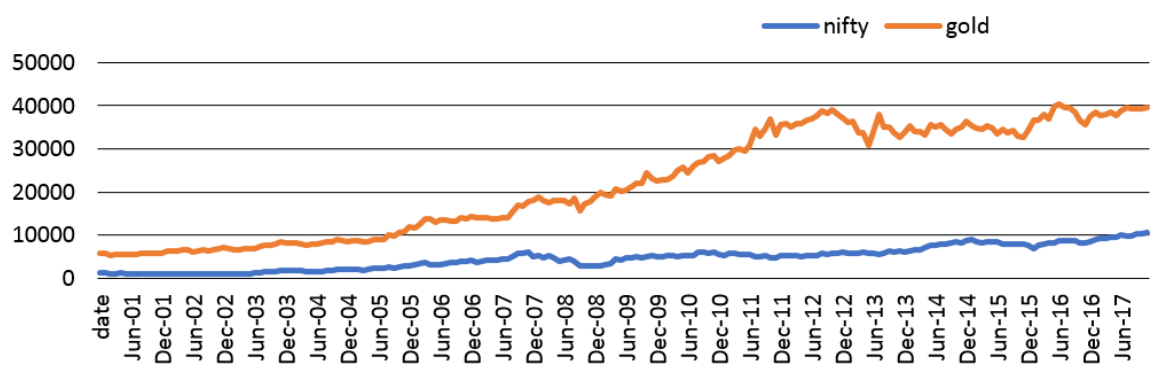

(Source - Author Own Calculation and Compliance)

\section{Fig. 1: Trend of Gold Returns and Nifty Returns}

From the above figure, it clearly shows that the gold return gives a tremendous result in the Indian market after 2004-05 and in the year 2007-08 it will grow on faster rate after India's first gold exchange-traded fund (Gold ETF) is created. The demand for the gold in the Indian market has increased due to rapid growth in urbanization, consumer incomes, and GDP. During the global financial crises when the majority of the stock exchange will fall down, at that time the consumption of the gold is increased in India (world gold council). India is highly dependent on gold because gold remains an integral part of social and religious customs, besides being the basic form of savings.

\section{Step -1: Preliminary Analysis: Testing of} Correlation \& Unit-Root.

This section presents the preliminary analysis of Unit-Roots testing \& correlation analysis of all the selected variables. Before going to the model, a preliminary analysis of testing regular unit roots and testing of correlation is required. For testing the correlation, Pearson coefficient of correlation (Table 1) and for stationarity, the tests statistics such as
Augmented Dickey-Fuller (ADF) and Phillip-Perron test are followed (Table No-2). The hypothesis of the Augmented Dickey-Fuller test and Phillip-Perron test of unit root is-

H0: The variables have unit root (Not Stationary).

H1: The variables have no unit root (Stationary).

\section{Correlation Analysis}

Table 1: Coefficient of Correlation of Selected Variables

\begin{tabular}{|c|c|c|}
\hline & Nifty & Gold \\
\hline Nifty & 1 & 0.86650906 \\
\hline Gold & 0.86650906 & 1 \\
\hline
\end{tabular}

(Source - Author Own Calculation and Compliance)

Pearson's coefficient of correlation method has been used to check the correlation and find out the strength of the relation between the gold price and nifty return. The table no-1 indicates that Nifty price, and Gold price, are showing a high correlation which indicates that's a good mathematical fit to a linear model.

\section{Testing of Unit-Root}

Table 2: Unit Root Test Statistics of Selected Variables

\begin{tabular}{|c|c|c|c|c|c|}
\hline \multirow{2}{*}{\multicolumn{2}{|c|}{\begin{tabular}{|c|} 
Test Stat \\
Variable Name
\end{tabular}}} & \multicolumn{2}{|c|}{$\begin{array}{c}\text { Augmented Dickey-Fuller } \\
\text { test statistic }\end{array}$} & \multicolumn{2}{|c|}{ Phillips-Perron test statistic } \\
\hline & & Nifty RTN & Gold Return & Nifty RTN & Gold Return \\
\hline \multirow{8}{*}{ 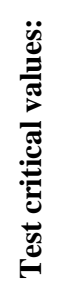 } & ADF test statistic & -13.37168 & -16.27926 & -13.41976 & -16.43613 \\
\hline & $1 \%$ level & -3.46274 & -3.46274 & -3.46274 & -3.46274 \\
\hline & $5 \%$ level & -2.87568 & -2.87568 & -2.87568 & -2.87568 \\
\hline & $10 \%$ level & -2.57439 & -2.57438 & -2.57439 & -2.57438 \\
\hline & R-squared & 0.47202 & 0.56991 & 0.47202 & 0.56991 \\
\hline & Adjusted R-squared & 0.46938 & 0.56776 & 0.46938 & 0.56776 \\
\hline & probability value & 0.00000 & 0.00000 & 0.00000 & 0.00000 \\
\hline & significance at & level & level & level & level \\
\hline
\end{tabular}

(Source - Author Own Calculation and Compliance) 
The empirical preliminary analysis starts with checking stationarity of the time series variables as a prerequisite for applying any time series model, for this study model like cointegration and causality test. The optimal lag length selection for the unit root tests are restricted to three for the sample size of 202 using a T1/3 formula. The Table no- 2 presents the results of ADF and PP unit root and the Results clearly indicates that both nifty return and the gold return is significant at level and become stationary because from the results of ADF and PP unit root implies that, both test statistics results are less than the critical value of $(1 \%),(5 \%),(10 \%)$ in both the test with the probability value less than $5 \%$. Hence, it can be concluded that the series are integrated of order one, i.e. I (1) at the $1 \%, 5 \%$ and $10 \%$ level of significance and the $\mathrm{HO}$ is rejected meaning that the nifty return and gold return does not have a unit root.

\section{Step-2: Secondary Analysis: Testing for Co- integration and Causation}

This section presents the secondary analysis of the variables with the objective to examine the cointegration and causal relationship between gold return and Nifty returns by applying Johansen's Co-Integration Test and Ganger causality test approach based on VAR framework along with the impulse response functions. The preliminary results in the step-1 suggest that the variable series are stationary at level, and the data are ready for the step- 2 models. The results of the Johansen Cointegration test are tabulated below-

\subsection{Johansen's Co-Integration Test}

Table 3: Johansen's Co-Integration Test

Unrestricted Cointegration Rank Test (Trace)

\begin{tabular}{|l|l|c|c|c|}
\hline $\begin{array}{c}\text { Hypothesized No. } \\
\text { of CE(s) }\end{array}$ & $\begin{array}{c}\text { Eigen } \\
\text { value }\end{array}$ & $\begin{array}{c}\text { Trace } \\
\text { Statistic }\end{array}$ & $\begin{array}{c}\text { 0.05 Critical } \\
\text { Value }\end{array}$ & Prob.** \\
\hline None $*$ & 0.183625 & 74.16635 & 15.49471 & 0.00000 \\
\hline At most 1 $*$ & 0.157765 & 33.99584 & 3.841466 & 0.00000 \\
\hline Trace test indicates 8 cointegrating eqn(s) at the 0.05 level \\
\hline$*$ denotes rejection of the hypothesis at the 0.05 level \\
\hline$* *$ MacKinnon-Haug-Michelis (1999) p-values
\end{tabular}

Unrestricted Cointegration Rank Test (Maximum Eigenvalue)

\begin{tabular}{|l|c|c|c|c|}
\hline $\begin{array}{c}\text { Hypothesized } \\
\text { No. of CE(s) }\end{array}$ & Eigen value & $\begin{array}{c}\text { Max-Eigen } \\
\text { Statistic }\end{array}$ & $\begin{array}{c}\text { 0.05 Critical } \\
\text { Value }\end{array}$ & Prob.** \\
\hline None * & 0.183625 & 40.17051 & 14.2646 & 0.00000 \\
\hline At most 1 * & 0.157765 & 33.99584 & 3.841466 & 0.00000 \\
\hline Max-eigenvalue test indicates 4 cointegrating eqn(s) at the 0.05 level \\
\hline$*$ denotes rejection of the hypothesis at the 0.05 level \\
\hline$* *$ MacKinnon-Haug-Michelis (1999) p-values
\end{tabular}

(Source - Author Own Calculation and Compliance)

Since the variables like nifty returns and gold are integrated (stationary) of order one (i.e. lag 1) in both ADF and PP methods. So, we move towards the examine the presence of long-run cointegrating relationship among the variables. The table no-3 reported the results of Johansen cointegration test. There are basically two types of test statistics are reported. The first block reports the so-called trace statistics ( $\lambda$ trace) and the second block reports the maximum eigenvalue ( $\lambda$ max) statistics. Both the trace statistic and the maximum eigenvalue statistics indicating that the nifty returns and gold is cointegrated at the 0.05 level. Hence, it will conclude that there is a long-run equilibrium relationship between gold and nifty returns in India. From this result, it also can be said that the international Gold Price Movements causes the Indian Stock Market Returns (Nifty Returns).

\subsection{Var lag order selection}

Table 4: Var lag length selection

\begin{tabular}{|c|c|c|c|c|c|c|}
\hline Lag & LogL & LR & FPE & AIC & SC & HQ \\
\hline 0 & 558.7166 & NA* & $1.14 \mathrm{e}-05^{*}$ & $-5.709914^{*}$ & $-5.676344^{*}$ & $-5.696322^{*}$ \\
\hline 1 & 561.151 & 4.79387 & $1.15 \mathrm{E}-05$ & -5.69386 & -5.59315 & -5.65308 \\
\hline 2 & 563.8028 & 5.167727 & $1.17 \mathrm{E}-05$ & -5.68003 & -5.51218 & -5.61207 \\
\hline 3 & 564.9962 & 2.301084 & $1.20 \mathrm{E}-05$ & -5.65124 & -5.41626 & -5.5561 \\
\hline 4 & 566.662 & 3.177805 & $1.23 \mathrm{E}-05$ & -5.6273 & -5.32518 & -5.50498 \\
\hline 5 & 567.9675 & 2.463805 & $1.27 \mathrm{E}-05$ & -5.59967 & -5.23041 & -5.45016 \\
\hline
\end{tabular}




\begin{tabular}{|l|l|l|l|l|l|l|}
\hline 6 & 570.2236 & 4.211291 & $1.29 \mathrm{E}-05$ & -5.58178 & -5.14538 & -5.40509 \\
\hline 7 & 571.2509 & 1.896547 & $1.33 \mathrm{E}-05$ & -5.55129 & -5.04775 & -5.34741 \\
\hline 8 & 573.3717 & 3.871912 & $1.36 \mathrm{E}-05$ & -5.53202 & -4.96134 & -5.30096 \\
\hline
\end{tabular}

Note; * indicates lag order selected by the criterion, LR: sequential modified LR test statistic (each test at $5 \%$ level), FPE: Final prediction error, AIC: Akaike information criterion, SC: Schwarz information criterion

(Source - Author Own Calculation and Compliance)

The table no 4 shows the VAR lag length selection based on different selection criteria like LR, FPE, AIC, SC and HQ. the VAR lag selection gives an option to what extent a researcher has taken the lag length, minimum lag order length is ' 0 'but zero lag order cannot be taken for analysis, so instead of zero 1lag order can be used and the maximum lag order is depending upon the researcher, but it will not give the appropriate results. In the present study, the Akaike information criterion (AIC) value is selected for the VAR lag. In the AIC the minimum value of AIC is good for the model.

\subsection{VAR Granger Causality Test}

Table 5: VAR Granger Causality Test

\begin{tabular}{|l|c|c|c|}
\hline Dependent variable: Nifty Return & & & \\
\hline Excluded & Chi-sq & df & Prob. \\
\hline Gold Return & 2.138809 & 2 & 0.343213 \\
\hline All & 2.138809 & 2 & 0.343213 \\
\hline Dependent variable: Gold Return & & & \\
\hline Excluded & Chi-sq & df & Prob. \\
\hline Nifty Return & 0.383846 & 2 & 0.82537 \\
\hline All & 0.383846 & 2 & 0.82537 \\
\hline
\end{tabular}

(Source - Author Own Calculation and Compliance)

From the previous results of the table 3 shows that the gold return has a significant impact on the stock market performance in long run. But in the table 5 shows that in short run, the gold return does not have any impact on stock market performance. From the results, it can be said that there is no direction between gold return and NSE Nifty returns in the short run.

From the overall results of table 2 and table 5 it can be said that Indians consider gold the safe haven investment as a financial asset and as jewellery. During the global financial crisis, most of the stock markets crashed but the gold price continues to increase in the country of India (world gold council). The results also indicate that India is highly dependent on gold because gold remains an integral part of social and religious customs, besides being the basic form of savings. As per the increasing demand of the gold in the Indian market, India's first gold exchange-traded fund (Gold ETF) was launched in 2007 and after that, it is found that the investors are gradually shifted their investment from physical investment to gold ETFs.

\subsection{Impulse Response Function}

The impulse response function of VAR is to analysis dynamic effects of the system when the model received the impulse. As per our VAR model, we have only two variables like gold price and stock return. We can work the response between these variables. The Impulse Response Functions analysis traces out the responsiveness of the dependent variable in VAR to shocks to each of the other explanatory variables over a period of time. (10 years taken in the present study). In order to display the response function clearer, we plot the Impulse Response chart as Fig. 2 and Fig. 3.

Table 6: Impulse Response Function

\begin{tabular}{|c|c|c|}
\hline \multicolumn{3}{|c|}{ Response of Nifty Return: } \\
\hline Period & Nifty Return & Gold Return \\
\hline 1 & 0.066740934 & 0.000000 \\
\hline 2 & 0.003693971 & -0.001997552 \\
\hline 3 & 0.000525654 & 0.006458617 \\
\hline 4 & -0.000093281 & -0.000461832 \\
\hline 5 & 0.000313070 & -0.000688486 \\
\hline 6 & -0.000000916 & 0.000151468 \\
\hline 7 & -0.000032947 & 0.00009174 \\
\hline 8 & 0.000004901 & -0.00003304 \\
\hline 9 & 0.000004780 & -0.00000947 \\
\hline 10 & -0.000001250 & 0.00000602 \\
\hline \hline \multicolumn{3}{|c|}{ Response of Gold Return: } \\
\hline Period & Nifty Return & Gold Return \\
\hline 1 & -0.003336675 & 0.049610813 \\
\hline 2 & -0.000512608 & -0.007918864 \\
\hline 3 & 0.002410943 & -0.005278208 \\
\hline 4 & -0.000217501 & 0.00173241 \\
\hline 5 & -0.000267957 & 0.000618282 \\
\hline 6 & 0.00006397 & -0.000330912 \\
\hline 7 & 0.00003443 & -0.00005154 \\
\hline 8 & -0.00001348 & 0.00005505 \\
\hline 9 & -0.00000345 & 0.00000123 \\
\hline
\end{tabular}




\begin{tabular}{|l|c|c|}
\hline 10 & 0.00000240 & -0.00000831 \\
\hline \multicolumn{2}{|c|}{ Cholesky Ordering: Nifty Return Gold } \\
Return \\
\hline
\end{tabular}

(Source - Author Own Calculation and Compliance)

One S.D. Innovations

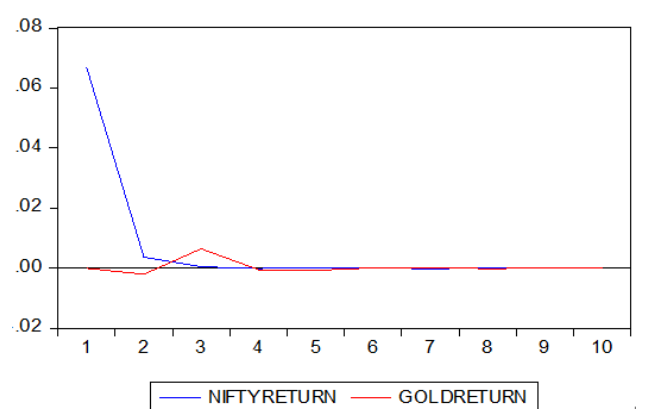

Fig. 2: Response of Stock Return

One S.D. Innovations

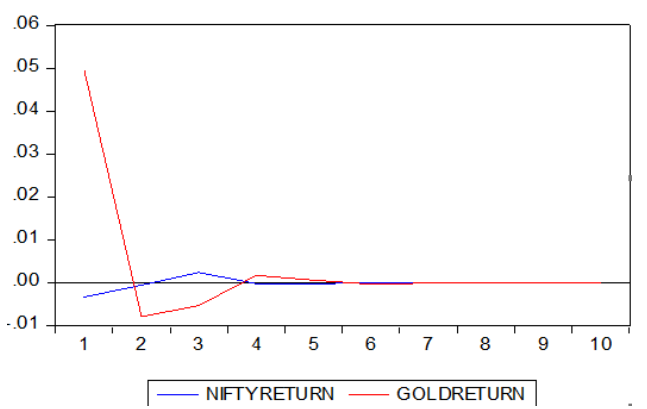

Fig. 3: Response of Gold Return

From the above figure no 1 and 2 the response of stock return and response of gold return is positive at maximum times responsive period except the $2^{\text {nd }}$ month. From the above impulse response results it can be said that the response of both the variables has a smooth fluctuation in upcoming $10^{\text {th }}$ period (month) because the present study will consider the monthly data.

\section{Conclusion}

In this paper, we provide evidence on the long-term as well as the short-run relation between gold price and stock return. Contrary to many previous studies, we employ the Johansen's co-integration and Granger causality based on VAR framework along with impulse response function, using data for India on monthly time series data for the period from January 2001 to December 2017. It is observed that the cointegration relationship exists between gold price and stock return. The Johansen's cointegration approach suggests that there is a long-run relationship between gold and stock return and the results of Granger causality approach suggest that there is no short-run relationship between gold price and stock return and the VAR computation suggest that gold is a safe option for investors in the Indian stock market. Based on these results, it can be concluded that the international gold price has significant information to forecast stock prices in India.
And also conclude that gold investment has the potential to safeguard short-term stock portfolios against negative extreme market shocks

\section{References}

1. Baig, M. M., Shahbaz, M., Imran, M., Jabbar, M., \& Ain, Q. U. (2013). Relationship between Gold and Oil Prices and Stock Market Returns. Economica, 9(5), 2839.

2. Balı, S., \& Cinel, M. O. (2011). ALTIN FIYATLARININ İMKB 100 ENDEKSİ'NE ETKİSİ ve BU ETKINININ ÖLÇÜMLENMESI. Atatürk

Üniversitesi İktisadi ve İdari Bilimler Dergisi, 25(3-4).

3. Batten, J. A., Ciner, C., \& Lucey, B. M. (2014). On the economic determinants of the gold-inflation relation. Resources Policy, 41, 101-108.

4. Beckmann, J., Berger, T., \& Czudaj, R. (2015). Does gold act as a hedge or a safe haven for stocks? A smooth transition approach. Economic Modelling, 48, 16-24.

5. Bhunia, A., \& Das, A. (2012). Association between gold prices and stock market returns: Empirical evidence from NSE. Journal of Exclusive Management Science, 1(2), 1-7.

6. Chkili, W. (2016). Dynamic correlations and hedging effectiveness between gold and stock markets: Evidence for BRICS countries. Research in International Business and Finance, 38, 22-34.

7. Erb, C. B., \& Harvey, C. R. (2006). The strategic and tactical value of commodity futures. Financial Analysts Journal, 62(2), 69-97.

8. Gorton, G., \& Rouwenhorst, K. G. (2006). Facts and fantasies about commodity futures. Financial Analysts Journal, 62(2), 47-68.

9. Gayathri, V., \& Dhanabhakyam, M. (2014). Cointegration and Causal Relationship between Gold Price and Nifty-An Empirical Study. Abhinav International Monthly Refereed Journal of Research in Management \& Technology, 3, 14-21.

10. Hood, M., \& Malik, F. (2013). Is gold the best hedge and a safe haven under changing stock market volatility? Review of Financial Economics, 22(2), 47 52.

11. Johansen, S. (1991). Estimation and hypothesis testing of cointegration vectors in Gaussian vector autoregressive models. Econometrica, 1551-1580.

12. Kumar, D. (2014). Return and volatility transmission between gold and stock sectors: application of portfolio management and hedging effectiveness. IIMB Management Review, 26(1), 5-16.

13. Levin, E. R., \& Wright, R. E. (2006). Short-run and long-run determinants of the price of gold. World Gold Council, Research Study, No. 32.

14. Mishra, P. K., Das, J. R., \& Mishra, S. K. (2010). Gold price volatility and stock market returns in India. American Journal of Scientific Research, 9, 47-55.

15. Mulyadi, M. S., \& Anwar, Y. (2012). Gold versus stock investment: An econometric analysis. International Journal of Development and Sustainability, 1(1), 1-7.

16. Narang, S. P., \& Singh, R. P. (2012). Causal relationship between gold price and Sensex: A study in Indian context. Vivekananda Journal of Research, 1(1), 33-37.

17. Raza, N., Ibrahimy, A. I., Ali, A., \& Ali, S. (2016). Gold and Islamic stocks: A hedge and safe haven comparison in time frequency domain for BRICS 
markets. The Journal of Developing Areas, 50(6), 305-

318.

18. Nguyen, C., Komornikova, M., Komornik, J., \& Bhatti, I. (2012). New Evidence on Asymmetric Comovement between Gold Prices and Stock Markets with Mixed-copula Analysis. In World Finance and Banking Symposium, December , 17-18.

19. Pukthuanthong, K., \& Roll, R. (2011). Gold and the Dollar (and the Euro, Pound, and Yen). Journal of Banking \& Finance, 35(8), 2070-2083.

20. Ray, S. (2013). Causal nexus between gold price movement and stock market: Evidence from Indian stock market. Sciknow Publications Ltd. Econometrics, (C) Attribution, 3, 12-19.

21. Reboredo, J. C. (2013). Is gold a safe haven or a hedge for the US dollar? Implications for risk management. Journal of Banking \& Finance, 37(8), 2665-2676.

22. Smith G (2001), "The Price of Gold and Stock Price Indices for the United States", World Gold Council Report, 1-35, available at http://www.gold.org/research/pricegold- and-stockprice-indices-united-states.

23. Shahzadi, H., \& Chohan, M. N. (2012). Impact of gold prices on stock exchange: A case study of Pakistan. KSE (Karachi Stock Exchange of Pakistan), Working Paper Series.

24. Sreekanth, D., \& Veni, L. K. (2014). Causal Relationship between Gold Price and Nifty-An Empirical Study in Indian Context. Asian Journal of Research in Banking and Finance, 4(5), 253-265.

25. Srinivasan P. \& Karthigai, P. (2014), Gold Price, Stock Price and Exchange Rate Nexus: The Case of India, The IUP Journal of Financial Risk Management, 11(3), 1-12.

26. Srinivasan, P., \& Prakasam, K. (2014). Gold price, stock price and exchange rate nexus: The case of India. IUP Journal of Financial risk management, 11(3), 52.

27. Toraman, C., Basarir, Ç., \& Bayramoglu, M. F. (2011). Determination of factors affecting the price of gold: A study of MGARCH model. Business and economics research journal, 2(4), 37.

28. Warren Buffett. (2012). Why stocks beat gold and bonds. Tucson: fortune.com

29. Wang, K.M., Lee, Y.M., \& Thi, T.B.N. (2011). Time and place where gold acts as an inflation hedge: An application of long-run and short-run threshold model. Economic Modelling, 28(3),806-819. 